\title{
Kesan Gelembung Udara dan Auksin bagi Penginduksian Akar pada Tunas Arundina graminifolia dalam Sistem Rendaman Berterusan Tertutup
}

(Effects of Air Bubbles and Auxin on Root Induction of Arundina graminifolia Shoots in Close Permanent Immerse System)

\author{
SAKINAH IDRIS, Che RADZIAH CHE MOHD. ZAIN* \& AB. KAHAR SANDRANG
}

\begin{abstract}
ABSTRAK
Arundina graminifolia atau orkid buluh adalah orkid yang hidup di atas tanah, tahan panas dan penyakit, mudah dijaga, berbunga sepanjang tahun dan sangat sesuai untuk dijadikan tanaman landskap di kawasan terbuka. Kebiasaannya, A. graminifolia dibiak melalui pembahagian rumpun dan kultur tisu. Kadar pembiakan daripada kaedah ini adalah sangat rendah dan mengambil masa yang lama untuk memperbanyakkan bahan tanaman. Penggunaan sistem rendaman berterusan tertutup (CPIS) telah berjaya mempercepatkan penginduksian mata tunas A. graminifolia. Namun, penginduksian akar mengambil masa yang agak lama iaitu melebihi tiga bulan. Oleh yang demikian, kajian ini bertujuan untuk menambahbaik sistem CPIS dengan menambah gelembung udara bagi mempercepatkan penginduksian akar pada tunas A. graminifolia. Seterusnya, penggunaan auksin asid naftalenasetik (NAA) dan asid indol-3-butirik (IBA) bagi meningkatkan peratus pengakaran pada tunas A. graminifolia turut dijalankan. Kehadiran gelembung udara di dalam sistem CPIS menunjukkan terdapat peningkatan yang signifikan untuk kelebaran, ketinggian dan kerenggangan mata tunas berbanding dengan CPIS tanpa kehadiran gelembung udara. Tunas yang terhasil dalam sistem CPIS dengan kehadiran gelembung udara juga mampu menghasilkan akar (10\% tunas yang berakar) berbanding dengan sistem CPIS tanpa kehadiran gelembung udara yang langsung tidak menghasilkan akar. Penginduksian akar pada tunas A. graminifolia menggunakan IBA dan NAA dengan kepekatan 0, 0.5, 1.0 dan 1.5 ppm menunjukkan perbezaan yang signifikan berbanding kawalan. Penggunaan hormon NAA dengan kepekatan yang semakin meningkat telah meningkatkan purata panjang akar, namun memberi kesan sebaliknya diperhatikan pada rawatan IBA. Kesimpulannya, sistem CPIS dengan kehadiran gelembung udara berserta hormon NAA 1.5 ppm mampu menginduksi dan meningkatkan peratus pengakaran A. graminifolia dengan lebih cepat.
\end{abstract}

Kata kunci: Arundina graminifolia; gelembung udara; hormon; penginduksian akar; sistem rendaman berterusan tertutup (CPIS)

\section{ABSTRACT}

Arundina graminifolia or bamboo orchid is a terrestrial orchid, heat, and disease resistant, easy to maintain, flowers throughout the year and suitable for outdoor landscapes. Commonly, A. graminifolia is propagated through the dividing of root mass and tissue culture. The rate of propagation via these techniques is very slow and take a long period to produce more planting materials. The use of closed permanent immerse systems (CPIS) has been successful in accelerating the shoot induction of A. graminifolia. However, its root induction takes a while, which is more than three months. Therefore, this study was aimed to improve the CPIS system by adding the presence of air bubbles to accelerate the root induction of A. graminifolia shoots. Furthermore, the use of auxins which are 1-naphthaleneacetic acid (NAA) and Indole-3-butyric acid (IBA) to increase the percentage of root induction on A. graminifolia shoot was also performed. The presence of air bubbles in the CPIS system showed a significant increase in shoot width, height and gap compared to the CPIS system without air bubbles. Shoots that were produced using the CPIS system with air bubbles are also able to produce root (10\% of rooting shoots) compared to the CPIS system without air bubbles that did not generate root at all. Root induction on A. graminifolia shoots using IBA and NAA at 0, 0.5, 1.0 and 1.5 ppm concentrations showed significant differences compared to control. Increasing of the NAA hormone concentrations increased the mean of root length, but opposite results were observed with IBA treatment. In conclusion, the CPIS system with air bubbles and 1.5 ppm NAA was able to induce and increase the percentage of rooting of A. graminifolia shoots in a short period.

Keywords: Air bubbles; Arundina graminifolia; closed permanent immerse system (CPIS); hormone; root induction 


\section{PENGENALAN}

Arundina graminifolia atau lebih dikenali sebagai orkid buluh di Malaysia merupakan spesies tunggal dalam genus Arundina yang banyak terdapat di Semenanjung Malaysia, Borneo dan beberapa negara di Asia dan Asia Tenggara seperti India dan Burma (O’Byrne 2001). A. graminifolia mempunyai ciri-ciri seperti hidup di atas tanah, tahan panas, mudah dijaga, rintang kepada serangan penyakit dan serangga perosak, memerlukan cahaya matahari sepenuhnya untuk pengeluaran bunga serta mampu berbunga sepanjang tahun (Rozlaily \& Engah 2012). Dalam kajian dan tinjauan oleh Deb (2013), A. graminifolia tersenarai dalam 54 spesies yang dikenal pasti sebagai bahan tanaman florikultur yang berpotensi untuk diterokai dan dikomersialkan. Di Malaysia, $A$. graminifolia $\mathrm{cv}$. suria dan mentari telah diisytiharkan pada Disember 2017. Sejurus selepas pengisytiharan, orkid ini mendapat perhatian dan tempahan yang menggalakkan dari Pihak Berkuasa Tempatan (PBT) seperti Dewan Bandaraya Kuala Lumpur (DBKL) dan pemaju perumahan seperti syarikat SP Setia (Idris et al. 2019a, 2019b). Permintaan yang meningkat ini juga telah mendorong ke arah perlunya kajian dijalankan bagi mendapatkan teknik pembiakan yang menghasilkan bahan tanaman $A$. graminifolia dengan banyak dalam masa yang singkat.

Sebelum ini, banyak kajian terhadap pembiakan spesies A. graminifolia dijalankan melalui kultur biji benih dan kultur tisu. Pembiakan A. graminifolia menggunakan kultur biji benih mengambil masa lebih dari dua tahun sebelum anak pokok dapat dipindahkan ke lapangan (Engah 2018). Sementara itu, pembiakan melalui kultur tisu telah dilakukan oleh beberapa penyelidik (Bhadra \& Bhowmik 2005; Chen et al. 2006; Das et al. 2013; Idris et al. 2017; Liu et al. 2005; Martin 2007; Nagaraju \& Parthasarathy 1995) dilaporkan juga mengambil masa pertumbuhan yang lama malah memerlukan protokol yang berkesan. Kajian yang dijalankan oleh Das et al. (2013) mendapati pembiakan A. graminifolia menggunakan teknik kultur tisu melalui penggunaan keratan batang satu nod sebagai sumber eksplan telah mengambil masa selama 45-47 hari untuk memecah dormansi tunas (bud break). Manakala kajian oleh Martin (2007) bagi membiak A. graminifolia melalui protocorm-like bodies (PLBs) yang dihasilkan daripada eksplan satu nod juga mengambil masa yang agak panjang iaitu 60 hari untuk menghasilkan protokom dan memerlukan tambahan masa lagi bagi menghasilkan anak pokok. Kajian awal yang telah dijalankan oleh Idris et al. (2019b) terhadap penginduksian mata tunas $A$. graminifolia melalui keratan batang tiga nod menggunakan sistem rendaman berterusan tertutup (CPIS) telah berjaya mempercepatkan penghasilan mata tunas $A$. graminifolia iaitu hanya 30 hari untuk menghasilkan 3 helai daun muda. Namun demikian, kekurangan sistem CPIS ini adalah ia mengambil masa yang agak lama untuk mata tunas mengeluarkan akar atau tidak mengeluarkan akar sama sekali. Akar hanya terhasil tiga bulan selepas mata tunas pecah (bud break) atau setelah mempunyai empat hingga lima helai daun matang. Justeru, kajian telah dijalankan dengan kehadiran gelembung udara bagi mempercepatkan penginduksian akar pada tunas $A$. graminifolia dalam sistem CPIS ini. Kajian penggunaan auksin asid naftalenasetik (NAA) dan asid indol-3-butirik (IBA) pada kepekatan 0, 0.5, 1.0 dan 1.5 ppm bagi meningkatkan peratus pengakaran pada tunas A. graminifolia turut dijalankan. Hasil kajian ini amat penting bagi memperoleh anak pokok $A$. graminifolia yang lengkap dengan kuantiti yang lebih banyak dan dalam tempoh yang lebih singkat.

\section{BAHAN DAN KAEDAH}

\section{SUMBER BAHAN TANAMAN}

A. graminifolia diperoleh dari Kompleks Orkid dan Bunga-bungaan plot penyelidikan orkid, Pusat Penyelidikan Hortikultur, ibu pejabat MARDI, Serdang, Selangor yang berkoordinat GPS 2.991894,-101.703491 $\left(+2^{\circ} 59^{\prime} 30.82,+101^{\circ} 42^{\prime} 12.57\right)$.

\section{PENYEDIAAN KERATAN BATANG}

Proses penyediaan keratan batang dilakukan dalam persekitaran bersih bagi mencegah risiko penyakit. Penggunaan alat pemotong yang sesuai, tajam dan bersih

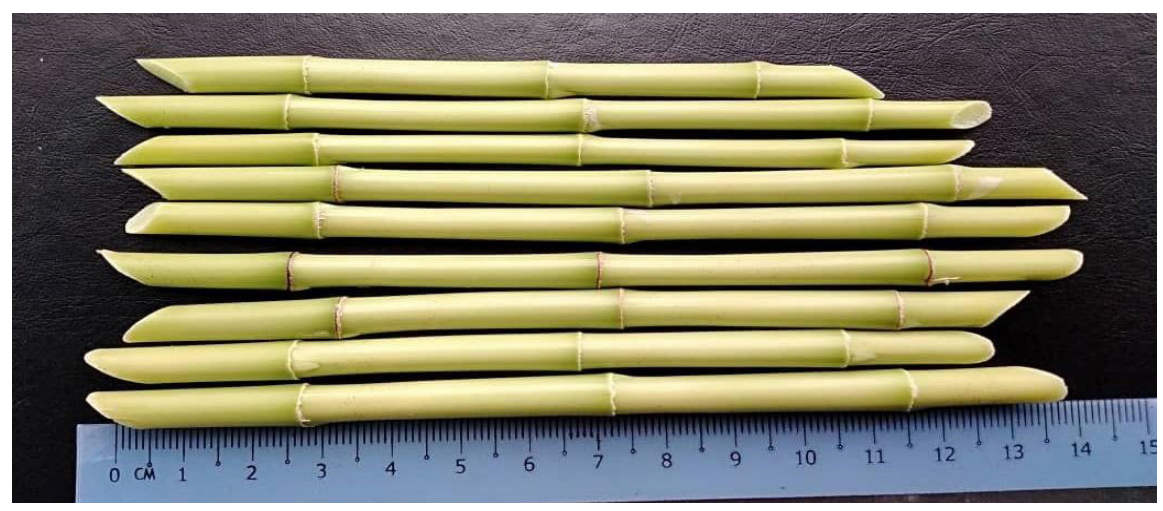

RAJAH 1. Keratan batang tiga nod (10-12 $\mathrm{cm}$ panjang dengan diameter 5-7 $\mathrm{mm}$ ) yang telah siap diproses dan sedia untuk digunakan dalam kajian 
harus diutamakan. Keratan batang yang seragam, sihat dan bebas daripada penyakit dipilih. Kesemua daun dan pelepah daun pada keratan batang terpilih dibuang untuk mendedahkan mata tunas. Keratan batang tiga nod dipotong dan dibasuh di dalam air yang mengalir selama 20 minit. Rajah 1 menunjukkan keratan batang yang telah siap diproses sedia untuk digunakan dalam kajian.

\section{PENYEDIAAN SISTEM CPIS}

Penyediaan sistem rendaman berterusan tertutup (CPIS) adalah seperti berikut. Sebuah takungan menggunakan kotak polisterina $(26 \times 38 \times 26 \mathrm{~cm})$ telah digunakan. Bahagian paling bawah setebal $5 \mathrm{~cm}$ tinggi ialah takungan air. Span yang dilubangkan dibiarkan terapung pada permukaan air bagi memudahkan keratan batang berada dalam keadaan tegak dan tidak tenggelam. Keratan batang hanya terendam antara $1.5-2.0 \mathrm{~cm}$ di bahagian bawah keratan batang. Bahagian tepi takungan mempunyai tiub untuk mengeluarkan air yang berlebihan. Struktur takungan ditutup menggunakan plastik lutsinar. Keratan rentas bagi sistem CPIS tanpa gelembung udara dan sistem CPIS dengan gelembung udara masing-masing ditunjukkan seperti Rajah 2 dan 3. Gelembung udara diberi dengan menggunakan pam udara yang dikawal oleh penetap masa. Pam udara dihidupkan selama empat jam setiap sesi, iaitu sebanyak tiga kali sehari. Sistem CPIS diletakkan di bawah $90 \%$ teduhan dengan suhu, kelembapan dan cahaya persekitaran masing-masing adalah $36 \pm 2^{\circ} \mathrm{C}, 94 \pm 3 \%$ dan 50 - $100 \mu \mathrm{mol} \mathrm{m}{ }^{2} / \mathrm{s}^{1}$. Bacaan suhu, kelembapan dan cahaya tersebut diambil semasa hari cerah antara pukul 12:00 tengah hari hingga 02:00 petang dalam sistem CPIS. Data fizikal sistem CPIS seperti suhu dan kelembapan diukur dengan menggunakan data logger (WatchDog 1000 Series Micro Stations). Manakala data cahaya diukur menggunakan meter cahaya (LI-COR LI-250A).

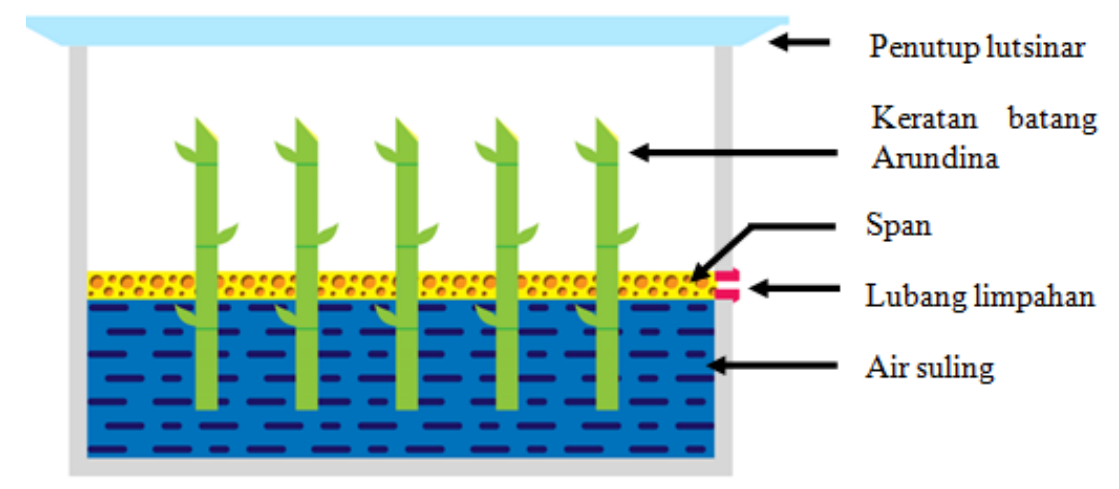

RAJAH 2. Keratan rentas sistem rendaman berterusan tertutup (CPIS) tanpa kehadiran gelembung udara

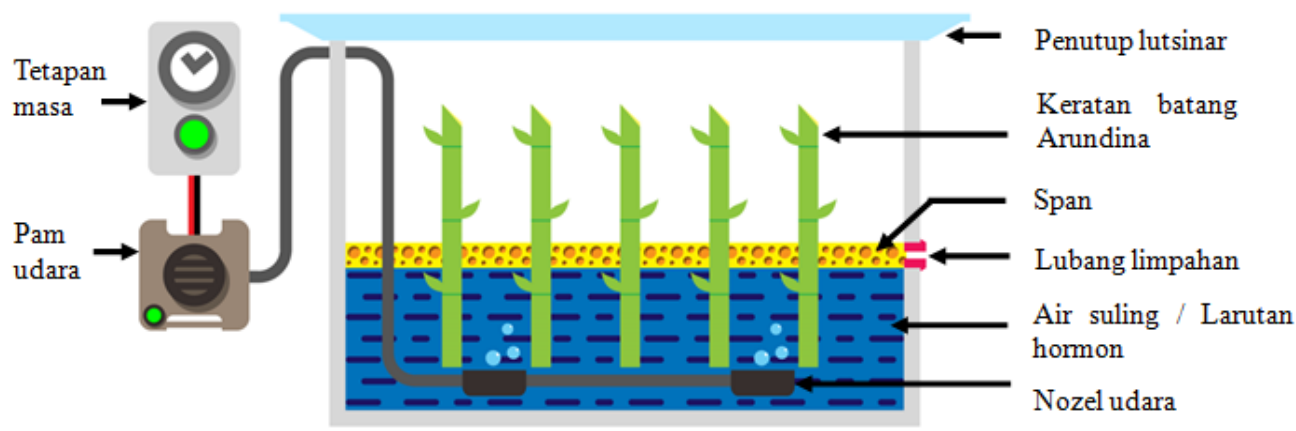

RAJAH 3. Keratan rentas sistem rendaman berterusan tertutup (CPIS) dengan kehadiran gelembung udara 


\section{PENYEDIAAN HORMON PENGAKARAN}

Perlakuan hormon penggalak akar yang mengandungi bahan aktif IBA dan NAA telah diberi secara langsung ke dalam sistem CPIS. Kepekatan kedua-dua larutan hormon adalah $0.5,1.0$ dan 1.5 bahagian dalam sejuta (ppm). Setiap larutan hormon perlu disediakan sebanyak 5 L bagi mencapai ketinggian $5 \mathrm{~cm}$ apabila dimasukan ke dalam sistem CPIS.

\section{REKA BENTUK UJI KAJI DAN ANALISIS STATISTIK}

Reka bentuk uji kaji yang digunakan adalah Randomize Complete Block Design (RCBD), empat replikasi dengan lima belas sampel keratan batang pada setiap plot kajian. Data tumbesaran tunas seperti lebar, tinggi dan renggangan tunas diukur menggunakan kaliper (Mitutoyo $150 \mathrm{~mm}$ Digital Caliper $0.01 \mathrm{~mm}$ ) dan direkod. Data keupayaan hidup dan bertunas dihitung pada minggu ke lapan seperti di dalam persamaan (1) dan (2). Data yang diperoleh dianalisis mengikut pakej Analisa SAS versi 9.3 untuk mendapatkan analisis varians (ANOVA). Seterusnya, perbandingan antara nilai purata perlakuan dilakukan mengikut kaedah Least Significance Difference (LSD).

Keupayaan hidup $(\%)=($ Jumlah keratan hidup/Jumlah keratan yang digunakan) $\times 100$

Keupayaan bertunas $(\%)=($ Jumlah keratan bertunas/ Jumlah keratan yang digunakan) $\times 100$

\section{KEPUTUSAN DAN PERBINCANGAN}

Dalam kajian penambahbaikan sistem CPIS dengan kehadiran gelembung udara, terdapat perbezaan bererti terhadap prestasi tumbesaran mata tunas. Sistem CPIS dengan kehadiran gelembung udara memberikan kelebaran tunas yang signifikan iaitu $3.15 \pm 0.06 \mathrm{~mm}$ berbanding dengan sistem CPIS tanpa kehadiran gelembung udara iaitu $2.91 \pm 0.07 \mathrm{~mm}$. Begitu juga yang berlaku pada ketinggian dan renggangan mata tunas. Sistem CPIS dengan kehadiran gelembung udara masingmasing memberikan ketinggian dan kerenggangan tunas yang lebih baik iaitu $16.15 \pm 1.27$ dan $10.56 \pm 2.08$ $\mathrm{mm}$ berbanding dengan sistem CPIS tanpa kehadiran gelembung udara $(13.90 \pm 0.83$ dan $6.66 \pm 0.54 \mathrm{~mm})$ seperti di dalam Jadual 1.

Malah dalam tempoh sebulan, $10 \%$ tunas yang terhasil dalam sistem CPIS dengan kehadiran gelembung udara juga mampu menghasilkan akar berbanding dengan sistem CPIS tanpa kehadiran gelembung udara yang langsung tidak menghasilkan akar. Sistem CPIS yang dibekalkan dengan gelembung udara memberikan gas hidrogen dan oksigen. Oksigen yang terhasil akan membantu penyerapan nutrien pada zon yang berpotensi menghasilkan akar pada tunas A. graminifolia ini. Hal ini juga disokong oleh Sari dan Bintoro (2016) yang menyatakan bahawa oksigen merupakan faktor penting dalam proses percambahan dan pertumbuhan tanaman. Oksigen yang terhasil berperanan dalam proses respirasi aerobik dengan proses penguraian gula (karbohidrat) hasil fotosintesis dan hasil akhir daripada proses respirasi iaitu terbentuknya molekul adenosina trifosfat (ATP) yang merupakan sumber tenaga utama bagi tanaman untuk melakukan semua kegiatan seperti penyerapan, transpirasi, pengangkutan, pembelahan sel, pembungaan mahupun fotosintesis.

Selain oksigen, kelembapan juga mempengaruhi kesuburan dan pertumbuhan sel (Sandrang 2009). Kelembapan berperanan penting dalam mempertahankan kestabilan bentuk sel (Wijayanto \& Nurunnajah 2012). Dalam kajian ini, sistem CPIS telah memberikan kelembapan udara yang tinggi di sekitaran keratan batang menyebabkan keratan batang kekal segar dan memberikan peratus hidup dan kejayaan terhadap pengakaran keratan batang A. graminifolia.

Dapat disimpulkan bahawa dengan penambahan gelembung udara, tumbesaran tunas dapat dioptimumkan dan dalam masa yang sama dapat merangsang pengakaran. Ini adalah kerana semua proses fisiologi dan metabolisme berlaku dengan lebih baik dan cekap. Selain itu, jumlah oksigen terlarut dalam air yang mencukupi dapat membantu penyerapan nutrien oleh tanaman dan seterusnya mempengaruhi pertumbuhan tanaman (Febriani et al. 2009; Izzati et al. 2006).

Disebabkan oleh peratus pengeluaran akar tunas dalam sistem CPIS yang dibekalkan gelembung udara masih lagi pada tahap yang rendah iaitu $10 \%$, kajian penambahbaikan sistem ini telah dijalankan dengan bantuan hormon auksin bagi meningkatkan peratus bilangan tunas berakar. Auksin memainkan peranan penting untuk memulakan pembentukan akar adventitius dan pembentukan akar primordia (Pagnussat et al. 2004). Auksin mendorong pembezaan sel parenkima dan masuk ke bahagian sel untuk membentuk meristem akar (Fujita \& Syono 1996; Klerk et al. 1995).

Dalam sistem CPIS yang dibekalkan dengan hormon pengakaran auksin IBA dan NAA, didapati bahawa keupayaan hidup dan keupayaan bertunas keratan batang A. graminifolia sedikit merosot berbanding kawalan. Kemerosotan keupayaan hidup dan keupayaan bertunas yang paling kritikal adalah pada penggunaan hormon IBA 1.5 ppm iaitu sebanyak 90\% kemerosotan. Keupayaan hidup dan keupayaan bertunas masingmasing ditunjukkan dalam Rajah 4 dan 5. Ini adalah kerana keupayaan hidup dan keupayaan bertunas sangat berkait rapat dengan tindakan osmotik di dalam sel batang A. graminifolia dan mempengaruhi pergerakan molekul hormon dalam sel batang tersebut.

Secara teorinya, penggunaan auksin akan meningkatkan kepekatan nitrik oksida yang 
menginduksikan pembentukan akar melalui isyarat pengekspresan protein pengaktifan mitogen atau mitogen activated protein kinase (MAPK) dan cyclic guanosine monophosphate (cGMP) yang mengawal atur pembahagian sel secara mitosis (Pagnussat et al. 2004, 2003). Hal ini juga disokong dalam kajian terdahulu yang menunjukkan bahawa kesan penggunaan auksin dapat meningkatkan kepekatan nitrik oksida bagi merangsang pembentukan akar adventitius dalam timun (Pagnussat et al. 2002), tembakau (Kumar \& Klessig 2000) dan Arabidopsis (Clarke et al. 2000). Transduksi isyarat dalam mempengaruhi pemanjangan sel tanaman dapat dijelaskan sebagai berikut, auksin memacu protein tertentu yang ada pada membran plasma sel tumbuhan untuk mengepam ion hidrogen ke dinding sel. Ion hidrogen ini mengaktifkan enzim tertentu sehingga memutuskan beberapa ikatan silang hidrogen rantai molekul selulosa dinding sel. Sel tumbuhan kemudian memanjang akibat air yang masuk secara osmosis. Setelah pemanjangan, sel terus tumbuh dengan mensintesis kembali bahan dinding sel dan sitoplasma (Febriani et al. 2009).

Hasil daripada kajian terhadap keupayaan hidup dan keupayaan bertunas dapat disimpulkan bahawa kedua-dua hormon NAA dan IBA pada kesemua kepekatan kecuali IBA pada kepekatan 1.5 ppm mungkin bersifat hipotonik (tekanan osmotik lebih rendah) atau isotonik (tekanan osmotik sama) terhadap cecair yang berada di dalam sel batang $A$. graminifolia. Dengan kata lain, kedua-dua hormon NAA dan IBA pada kesemua kepekatan kecuali IBA pada kepekatan 1.5 ppm mempunyai nilai keupayaan air tinggi yang membolehkan pergerakan hormon memasuki membran sel secara osmosis. Hormon IBA $1.5 \mathrm{ppm}$ pula lebih bersifat hipertonik iaitu mempunyai tekanan osmotik lebih tinggi daripada cecair yang berada di dalam sel batang A. graminifolia. Ini bermakna, hormon IBA 1.5 ppm mempunyai nilai keupayaan air rendah yang mungkin menghalang pergerakan hormon memasuki membran sel tumbuhan di samping menyebabkan air di dalam sel batang tumbuhan keluar. Ini boleh menyebabkan kesegahan sel berkurangan dan seterusnya keratan batang $A$. graminifolia menjadi kekuningan, mengecut dan akhirnya mati. Hal ini boleh dilihat dengan jelas pada keupayaan hidup dan keupayaan bertunas keratan batang A. graminifolia yang sangat rendah pada larutan IBA 1.5 ppm (Rajah 4 dan 5).

Berdasarkan Jadual 2, terdapat perbezaan yang signifikan antara kepekatan hormon yang digunakan terhadap lebar tunas, tinggi tunas, bilangan daun dan juga panjang akar. Prestasi tumbesaran mata tunas terhadap lebar tunas dan bilangan daun menunjukkan perbezaan yang kecil kecuali pada tumbesaran tinggi tunas. Purata tinggi tunas tertinggi adalah pada penggunaan hormon NAA 1.5 ppm $(31.55 \pm 2.31 \mathrm{~mm})$. Penggunaan kepekatan hormon yang sesuai ternyata dapat meningkatkan peratus bilangan tunas yang menghasilkan akar adventitius (kecuali 1.5 ppm IBA) dan sekaligus dapat mempercepatkan pemanjangan akar tersebut. Peratus bilangan tunas berakar tertinggi dan terendah masing-masing adalah pada hormon NAA 1.5 ppm (75\%) dan IBA 1.5 ppm (2\%).

Kepekatan hormon NAA pada $1.5 \mathrm{ppm}$ dan 0.5 ppm telah memberi purata panjang akar terpanjang dan terpendek iaitu masing-masing $17.18 \pm 4.45 \mathrm{~mm}$ dan $4.03 \pm 1.60 \mathrm{~mm}$ selepas lapan minggu pemerhatian dilakukan. Rajah 6 menunjukkan pengakaran tunas $A$. graminifolia dengan penggunaan hormon NAA $1.5 \mathrm{ppm}$ berbanding dengan kawalan pada umur empat dan lapan minggu.

Penggunaan hormon NAA dengan kepekatan yang semakin meningkat dapat meningkatkan purata panjang akar dan juga peratus bilangan tunas berakar. Manakala, penggunaan hormon IBA dengan kepekatan yang semakin tinggi telah menyebabkan kemerosotan terhadap purata panjang akar juga peratus bilangan tunas berakar. Namun penggunaan hormon IBA pada kepekatan yang lebih rendah seperti $0.1,0.2$ atau $0.3 \mathrm{ppm}$ mungkin dapat memberi peratus keupayaan hidup, keupayaan bertunas dan pengakaran yang lebih baik. Manakala penggunaan hormon NAA pada kepekatan yang lebih tinggi seperti 2.0 hingga $5.0 \mathrm{ppm}$ mungkin dapat memberi kesan pengakaran yang lebih optimum.

Hartmann dan Kester (1975) melaporkan bahawa penggunaan hormon pertumbuhan daripada jenis auksin pada keratan batang boleh menggalakkan pertumbuhan akar. Walau bagimanapun, terdapat juga kesan negatif pada keratan seperti pertumbuhan tunas terbantut, daun menjadi kuning, daun gugur dan keratan batang akan mati sekiranya kepekatan bahan ini digunakan dengan berlebihan. Hopkins dan Hüner (2004) juga menyatakan bahawa penggunaan auksin yang melebihi had optimum akan merencatkan pertumbuhan sesuatu tanaman. Hal ini dapat diperhatikan dengan penggunaan hormon IBA 1.5 ppm yang memberi kesan negatif terhadap keratan batang.

Walaupun begitu, hasil yang diperoleh dalam kajian ini adalah lebih baik berbanding kajian terdahulu oleh Idris et al. (2019a). Kajian awal terhadap penginduksian mata tunas A. graminifolia melalui keratan batang tiga nod menggunakan sistem CPIS telah berjaya menghasilkan mata tunas dalam tempoh 30 hari dengan tiga helai daun muda (Idris et al. 2019b). Tempoh 30 hari ini adalah jauh lebih cepat berbanding kajian lepas ke atas A. graminifolio (Das et al. 2013; Martin 2007). Kajian yang dijalankan oleh Das et al. (2013) mengambil masa selama 45 hingga 47 hari untuk memecah kedormanan tunas. Kajian oleh Martin (2007) pula mengambil masa 60 hari untuk menghasilkan protokom dan memerlukan tambahan masa lagi bagi menghasilkan anak pokok. 
JADUAL 1. Prestasi pertumbuhan mata tunas di dalam sistem CPIS dengan kehadiran dan tanpa kehadiran gelembung udara pada usia empat minggu

\begin{tabular}{lcc}
\hline \multicolumn{1}{c}{ Sistem } & CPIS dengan gelembung udara & CPIS tanpa gelembung udara \\
\hline Lebar tunas $(\mathrm{mm}) \pm \mathrm{SE}$ & $3.15 \pm 0.06^{\mathrm{a}}$ & $2.91 \pm 0.07^{\mathrm{b}}$ \\
Tinggi tunas $(\mathrm{mm}) \pm \mathrm{SE}$ & $16.15 \pm 1.27^{\mathrm{a}}$ & $13.90 \pm 0.83^{\mathrm{b}}$ \\
Renggangan tunas $(\mathrm{mm}) \pm \mathrm{SE}$ & $10.56 \pm 2.08^{\mathrm{a}}$ & $6.66 \pm 0.54^{\mathrm{b}}$ \\
Tempoh berakar & 4 minggu & Tidak berakar \\
Bilangan tunas berakar & $10 \%$ & $0 \%$ \\
Panjang akar $(\mathrm{mm}) \pm \mathrm{SE}$ & $1.28 \pm 0.23^{\mathrm{a}}$ & 0 \\
\hline
\end{tabular}

Nilai dalam baris yang sama yang mempunyai huruf yang sama tidak berbeza dengan signifikan pada $\mathrm{p}<0.05$ mengikut ujian LSD

JADUAL 2. Tindak balas tunas terhadap penginduksian akar $A$. graminifolia dengan menggunakan hormon IBA dan NAA pada kepekatan 0, 0.5, 1.0 dan 1.5 ppm pada usia lapan minggu

\begin{tabular}{lcccccc}
\hline $\begin{array}{c}\text { Kepekatan } \\
\text { hormon }(\mathrm{ppm})\end{array}$ & $\begin{array}{c}\text { Lebar tunas } \\
(\mathrm{mm}) \pm \mathrm{SE}\end{array}$ & $\begin{array}{c}\text { Tinggi tunas } \\
(\mathrm{mm}) \pm \mathrm{SE}\end{array}$ & $\begin{array}{c}\text { Bilangan daun } \\
(\mathrm{mm}) \pm \mathrm{SE}\end{array}$ & $\begin{array}{c}\text { Tempoh } \\
\text { berakar } \\
(\text { minggu })\end{array}$ & $\begin{array}{c}\text { Bil. tunas } \\
\text { berakar }(\%)\end{array}$ & $\begin{array}{c}\text { Panjang akar } \\
(\mathrm{mm}) \pm \mathrm{SE}\end{array}$ \\
\hline 0 & $3.53 \pm 0.05^{\mathrm{bc}}$ & $27.6 \pm 2.93^{\mathrm{bc}}$ & $4.25 \pm 0.11^{\mathrm{bc}}$ & $4-8$ & 12 & $2.56 \pm 1.10^{\mathrm{a}}$ \\
NAA 0.5 & $3.81 \pm 0.12^{\mathrm{ab}}$ & $27.19 \pm 2.90^{\mathrm{bc}}$ & $4.5 \pm 0.12^{\mathrm{ab}}$ & $4-6$ & 35 & $4.03 \pm 1.60^{\mathrm{cd}}$ \\
NAA 1 & $3.76 \pm 0.23^{\mathrm{ab}}$ & $24.83 \pm 2.36^{\mathrm{bc}}$ & $4.75 \pm 0.11^{\mathrm{a}}$ & $4-6$ & 70 & $11.96 \pm 3.02^{\mathrm{abc}}$ \\
NAA 1.5 & $3.72 \pm 0.13^{\mathrm{ab}}$ & $31.55 \pm 2.31^{\mathrm{ab}}$ & $4.5 \pm 0.12^{\mathrm{ab}}$ & $4-6$ & 75 & $17.18 \pm 4.45^{\mathrm{a}}$ \\
IBA 0.5 & $3.67 \pm 0.09^{\mathrm{abc}}$ & $28.59 \pm 2.63^{\mathrm{bc}}$ & $4.54 \pm 0.12^{\mathrm{ab}}$ & $4-6$ & 18 & $7.12 \pm 3.01^{\mathrm{bcd}}$ \\
IBA 1 & $3.68 \pm 0.11^{\mathrm{abc}}$ & $23.48 \pm 2.42^{\mathrm{c}}$ & $4.54 \pm 0.12^{\mathrm{ab}}$ & $4-6$ & 15 & $6.17 \pm 2.01^{\mathrm{bcd}}$ \\
IBA 1.5 & $3.96 \pm 0.04^{\mathrm{a}}$ & $28.58 \pm 1.76^{\mathrm{bc}}$ & $4.75 \pm 0.11^{\mathrm{a}}$ & $4-6$ & 2 & $5.87 \pm 1.74^{\mathrm{bcd}}$
\end{tabular}

Nilai dalam lajur yang sama yang mempunyai huruf yang sama tidak berbeza dengan signifikan pada $\mathrm{p}<0.05$ mengikut ujian LSD

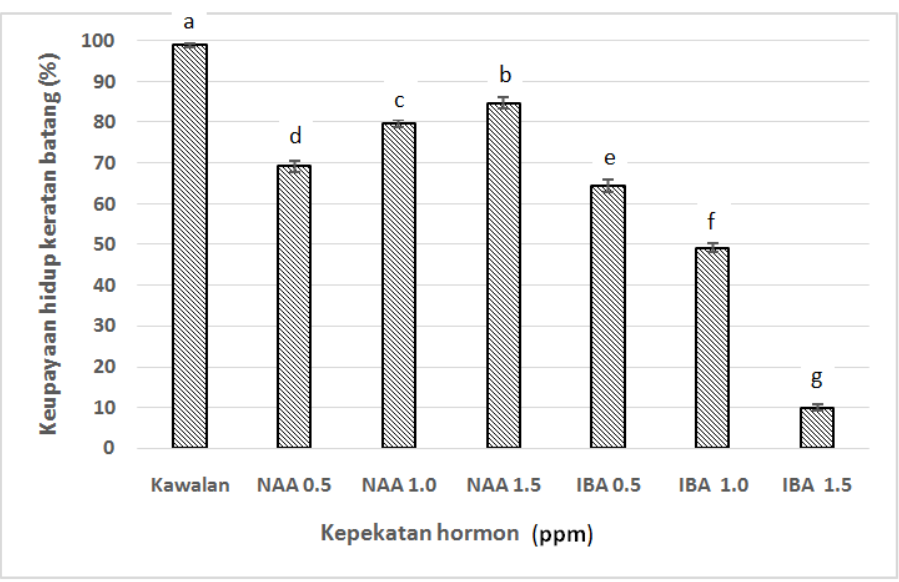

RAJAH 4. Peratus keupayaan hidup keratan batang di dalam sistem CPIS + gelembung udara dengan menggunakan hormon NAA dan IBA pada kepekatan $0.5,1.0$ dan 1.5 ppm pada minggu ke lapan 


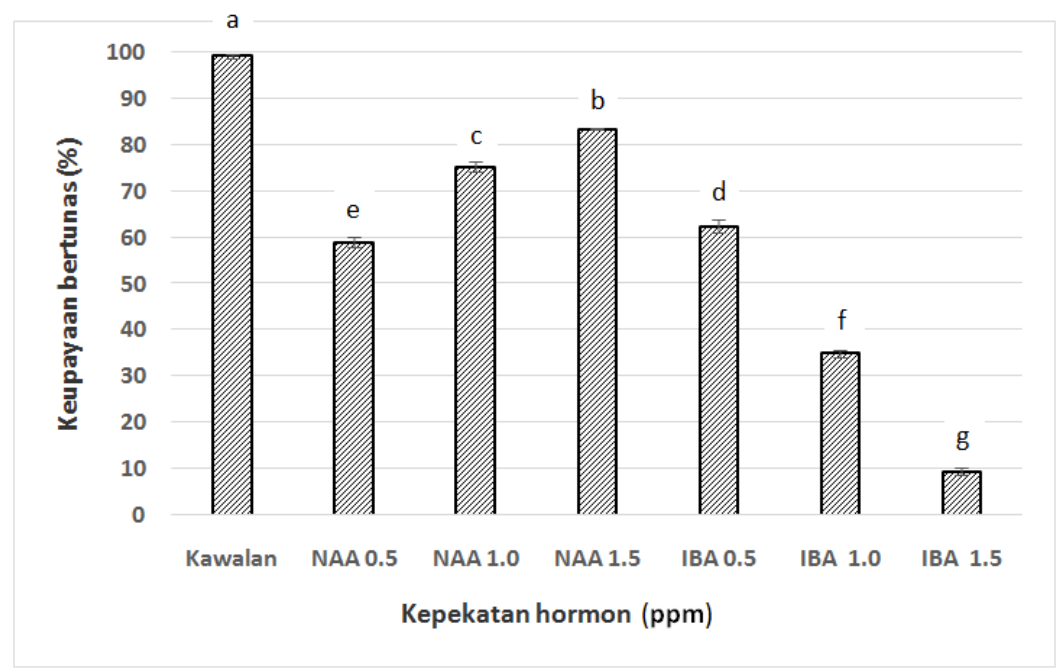

RAJAH 5. Peratus keupayaan bertunas di dalam sistem CPIS + gelembung udara dengan menggunakan hormon NAA dan IBA pada kepekatan $0.5,1.0$ dan $1.5 \mathrm{ppm}$ pada minggu ke lapan

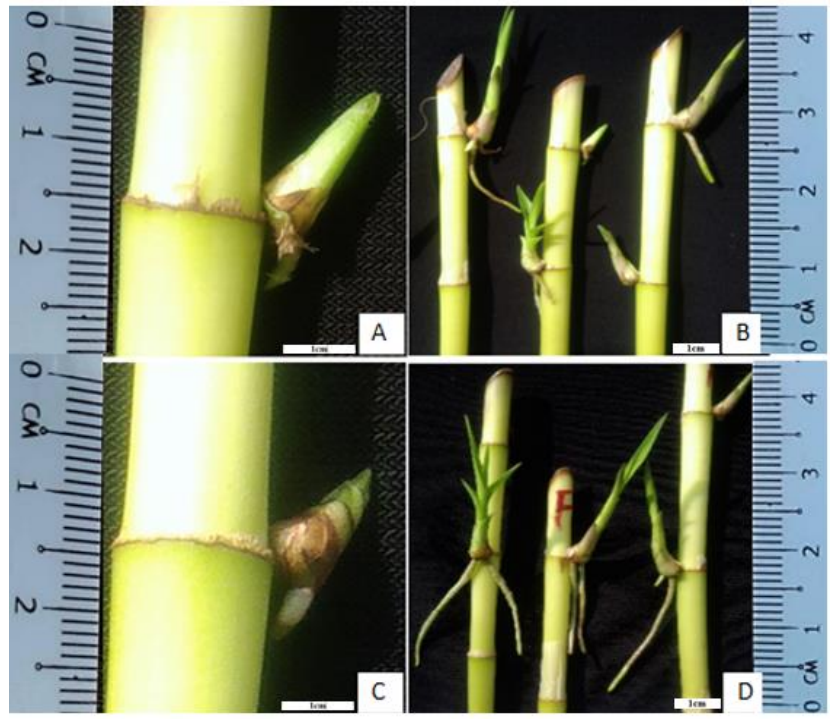

RAJAH 6. Perbandingan akar antara kawalan dengan hormon NAA 1.5 ppm pada usia empat dan lapan minggu. (A) Kawalan pada usia empat minggu, (B) Kawalan pada usia lapan minggu, (C) NAA 1.5 ppm pada usia empat minggu dan (D) NAA $1.5 \mathrm{ppm}$ pada usia lapan minggu. (skala bar, $1 \mathrm{~cm}$ )

\section{KESIMPULAN}

Sistem CPIS dengan kehadiran gelembung udara telah menunjukkan prestasi pertumbuhan tunas $A$. graminifolia yang optimum dan signifikan berbanding CPIS tanpa kehadiran gelembung udara. Penggunaan hormon IBA dan NAA pula dapat meningkatkan peratus pengakaran pada tunas A. graminifolia. Ringkasnya, sistem CPIS dengan kehadiran gelembung udara berserta hormon 
NAA berkepekatan $1.5 \mathrm{ppm}$ adalah rawatan terbaik bagi menginduksi dan meningkatkan peratus pengakaran $A$. graminifolia dalam tempoh yang singkat iaitu selama sebulan.

\section{PENGHARGAAN}

Penulis merakamkan setinggi-tinggi penghargaan kepada Institut Penyelidikan dan Kemajuan Pertanian Malaysia (MARDI) kerana telah membiayai pengajian penulis dan juga kakitangan MARDI yang terlibat dalam menjayakan kajian ini.

\section{RUJUKAN}

Bhadra, S.K. \& Bhowmik, T.K. 2005. Axenic germina germination of seeds and rhizome-based micropropagation of an orchid Arundina graminifolia (D. Don.) Hochr. Bangladesh Journal of Botany 34(2): 59-64.

Chen, Z., Zeng, S. \& Wen, T. 2006. Asepsis sowing and in vitro propagation of Arundina graminifolia Hochr. Plant Physiology Communications 42(1): 66.

Clarke, A., Desikan, R., Hurst, R.D., Hancock, J.T. \& Neill, S.J. 2000. NO way back: Nitric oxide and programmed cell death in Arabidopsis thaliana suspension cultures. Plant Journal 24(5): 667-677.

Das, S., Choudhury, M.D. \& Mazumder, P.B. 2013. In vitro propagation of Arundina graminifolia (D.Don) Hochr - a bamboo orchid. Asian Journal of Pharmaceutical and Clinical Research 6(5): 156-158.

Deb, C.R. 2013. Orchids of Nagaland, propagation, conservation and sustainable utilization: A review. Pleione 7(1): 52-58

Engah. W.R.W. 2018. http://www.utusan.com.my/sains teknologi sains/orkid tahan panas (C) Utusan Melayu (M) Bhd.

Febriani, T.P., Damranti, S. \& Raharjo, B. 2009. Pengaruh konsentrasi dan lama perendaman dalam supernatan kultur Bacillus sp.2 DUCC-BR-KI.3 terhadap pertumbuhan stek horisontal batang jarak pagar (Jatropa curcas L.). Jabatan Sains \& Matematika 17(3): 131-140.

Fujita, H. \& Syono, K. 1996. Genetic analysis of the effects of polar auxin transport inhibitors on root growth in Arabidopsis thaliana. Plant and Cell Physiology 37(8): 1094-1101.

Hartmann, H.T. \& Kester, D.E. 1975. Plant Propagation: Principles and Practices. 4th ed. New Jersey. Prentice Hall. m.s. 727.

Hopkins, W.G. \& Hüner, N.P.A. 2004. Introduction to Plant Phsiology. London, Ontario: John Wiley \& Sons, Inc. m.s. 17-27.

Idris, S., Zain, C.R.C.M., Sandrang, A.K. \& Engah, W.R.W. 2019a. A preliminary study on propagation system to induce shoot-bud proliferation of Arundina graminifolia. Dlm. 28th Malaysian Society of Plant Physiology Conference (MSPPC 2018), Challenges and Strategies for Plant Productivity and Resilience, Kelantan, Malaysia. m.s. 71-74.

Idris, S., Sandrang, A.K. \& Zain, C.R.C.M. 2019b. Vegetative propagation of Arundina graminifolia: Influences of node numbers, physiological age and position of cutting for best shoot-bud proliferation. International Journal of Agriculture, Forestry and Plantation 8: 36-39.

Idris, S., Zain, C.R.C.M., Sandrang, A.K., Engah, W.R.W. \& Nurul Enanee, A.K. 2017. Proliferasi tunas hibrid baharu Arundina graminifolia $\mathrm{sp}$. tempatan $\times$ Arundina graminifolia sp. India menggunakan sistem rendaman sementara. Dlm. Prosiding Persidangan Kebangsaan Pemindahan Teknologi (CONFERTECH). m.s. 282-285.

Izzati, I.R., Ketty, S. \& Winarso, D.W. 2006. Penggunaan pupuk majemuk sebagai sumber hara pada budidaya selada (Lactuca sativa L.) secara hidroponik dengan tiga cara fertigasi. Dlm. Prosiding Seminar Nasional PERHORTI. m.s. 153-164.

Klerk, G.J.D., Keppel, M., Brugge, J.T. \& Meekes, H. 1995. Timing of the phases in adventitious root formation in apple microcuttings. Journal of Experimental Botany 46(8): 965972.

Kumar, D. \& Klessig, D.F. 2000. Differential induction of tobacco MAP kinases by the defense signals nitric oxide, salicylic acid, ethylene and jasmonic acid. Molecular Plant-Microbe Interactions 13(3): 347-351.

Liu, M.F., Ding, Y. \& Zhang, D.M. 2005. Phenanthrene constituents from rhizome of Arundina graminifolia. China Journal of Chinese Materia Medica 30(5): 353-356.

Martin, K.P. 2007. Micropropagation of the bamboo orchid (Arundina graminifolia (D. Don) Hochr.) through protocorm-like-bodies using node explants. Propagation of Ornamental Plants 7(2): 97-100.

Nagaraju, V. \& Parthasarathy, V.S. 1995. In vitro propagation of plaius and bamboo orchid by shoot tip culture. Annals of Plant Physiology 9: 102-104.

O'Byrne, P. 2001. A to Z of South East Asia Orchid Species. Singapore: Orchid Society of South East Asia.

Pagnussat, G.C., Lanteri, M.L., Lombardo, M.C. \& Lamattina, L. 2004. Nitric oxide mediates the indole acetic acid induction activation of a mitogen-activated protein kinase cascade involved in adventutios root development. Plant Physiology 135(1): 279-286

Pagnussat, G.C., Lanteri, M.L. \& Lamattina, L. 2003. Nitric oxide and cyclic GMP are messengers in the indole acetic acid-induced adventitious rooting process. Plant Physiology 132(3): 1241-1248

Pagnussat, G.C., Simontacchi, M., Puntarulo, S. \& Lamattina, L. 2002. Nitric oxide is required for root organogenesis. Plant Physiology 129(3): 954-956.

Rozlaily, Z. \& Engah, W.R.W. 2012. Orkid eksotik untuk landskap. Dlm. Prosiding Persidangan Kebangsan Pemindahan Teknologi (CONFERTECH). m.s. 82-85.

Sandrang, K.A., Sayuti, Z. \& Ahmad, H. 2009. Sistem pembiakan kapilari tertutup untuk keratan batang. Buletin Teknologi Tanaman 6: 9-13

Sari, E. \& Bintoro, A. 2016. Betung Bamboo (Dendrocalamus asper) branch cutting response to indole butyric acid (IBA). Journal Sylva Lestari 4(2): 61-68.

Wijayanto, N. \& Nurunnajah, N. 2012. Intensitas cahaya, suhu, kelembaban dan perakaran lateral mahoni (Swietenia macrophylla King.) di RPH Babakan Madang, BKPH Bogor, KPH Bogor. Jurnal Silvikultur Tropika 3(1): 8-13. 
Sakinah Idris \& Che Radziah Che Mohd Zain* Jabatan Sains Biologi dan Bioteknologi

Fakulti Sains dan Teknologi

Universiti Kebangsaan Malaysia

43600 UKM Bangi, Selangor Darul Ehsan

Malaysia

Ab. Kahar Sandrang

Pusat Penyelidikan Hortikultur

Ibu Pejabat MARDI

43400 Serdang, Selangor Darul Ehsan

Malaysia
*Pengarang untuk surat-menyurat; email: cradziah@ukm.edu.my

Diserahkan: 25 September 2019

Diterima: 9 Mei 2020 